\title{
Pola Penyakit dan Karakteristik Pasien Hemato- Onkologi Bagian IImu Kesehatan Anak Fakultas Kedokteran Universitas Udayana/RS Sanglah Denpasar Periode 2000-2005
}

\author{
Ida Bagus Mudita \\ Bagian/SMF Ilmu Kesehatan Anak, Fakultas Kedokteran Universitas Udayana/RS Sanglah Denpasar
}

\begin{abstract}
Latar belakang. Data epidemiologi kasus hematologi onkologi anak di Indonesia belum ada, hal ini karena sistem registrasi dilakukan secara nasional. Data tersebut penting karena selain memberikan gambaran situasi kesehatan juga dapat digunakan bagi peningkatan pelayanan dan penelitian.

Tujuan Penelitian. Mengetahui pola penyakit dan karakteristik pasien hemato-onkologi di Bagian/SMF Ilmu Kesehatan Anak RS Sanglah.

Metode. Penelitian deskriptif, restropektif dari Januari 2000 sampai Desember 2005.

Hasil. Didapatkan 215 kasus yang terdiri dari 39 jenis penyakit. Leukemia limfoblastik akut (LLA) merupakan kasus hemato-onkologi terbanyak (23,7\%) yang juga merupakan kasus hematologi terbanyak $(29,8 \%)$, sedangkan retinoblastoma merupakan kasus onkologi terbanyak $(38,6 \%)$. Terbanyak kasus $(48,4 \%)$ berusia 1-5 tahun. Didapatkan 8,4\% kasus meninggal terutama kasus LLA.

Kesimpulan. Leukemia limfoblastik akut dan retinoblastoma merupakan kasus hematologi dan onkologi terbanyak. Usia terbanyak adalah usia 1-5 tahun. Angka kematian sebesar 8,4\% terbanyak kasus LLA (Sari Pediatri 2007; 9(10):13-16)
\end{abstract}

Kata kunci: kasus hematologi-onkologi, pola penyakit, karakteristik

$\mathrm{K}$ asus hemato-onkologi anak merupakan kasus-kasus yang memerlukan perhatian dan kesabaran dalam tata laksananya. Pasien hemato-onkologi akan memerlukan

\footnotetext{
Alamat korespondensi

Dr. Ida Bagus Mudita

Bagian/SMF Ilmu Kesehatan Anak, FK Unud/RS Sanglah Denpasar, Jalan P Nias, Denpasar.

Telepon: 0361 227911-227915 Pes. 128. Fax.: 0361244038
}

perawatan dan pengobatan jangka panjang serta persiapan fisik dan mental, baik untuk pasien maupun keluarganya dalam menghadapi segala kemungkinan.

Seiring dengan meningkatnya pengetahuan masyarakat serta berkembangnya ilmu pengetahuan dan teknologi di bidang kedokteran, maka kasus hematoonkologi yang dahulu asing atau bahkan tidak tertangani, saat ini sudah mulai terdiagnosis. Diagnosis sudah dapat ditegakkan sedini mungkin sehingga tata laksana yang tepat dapat segera dilakukan, akhirnya dapat menambah 
usia harapan hidup, dengan memperbaiki kualitas hidup serta mengoptimalkan tumbuh kembang anak. ${ }^{1}$ Tata laksana kasus harus dilakukan secara komperehensif sehingga didapatkan hasil yang optimal. ${ }^{2}$

Data epidemiologi mengenai kasus-kasus hematoonkologi anak di Indonesia secara keseluruhan tidak jelas. Hal ini terjadi karena kurangnya sistem pencatatan pasien secara terpadu. Masing-masing pusat kesehatan di daerah hanya memiliki data di bagian mereka sendiri saja. Data ini sangatlah penting karena akan menggambarkan kasuskasus apa saja yang ada dan mendominasi sehingga dapat dipersiapkan penatalaksanaan yang memadai mengingat terbatasnya alat, sarana, dan tenaga ahli.

Demikian pula halnya di Subdivisi HematoOnkologi Bagian/SMF Ilmu Kesehatan Anak FK UNUD/RS Sanglah Denpasar, data mengenai kasus hemato-onkologi yang dirawat belum memadai. Penelitian ini dilakukan untuk memperoleh pola penyakit dan karakteristik pasien hemato-onkologi di Bagian/SMF Ilmu Kesehatan Anak FK UNUD/RS
Sanglah Denpasar. Data yang diperoleh akan dipakai sebagai data dasar untuk penelitian selanjutnya.

\section{Metode}

Penelitian ini adalah penelitian deskriptif yang dilakukan secara retrospektif. Data diperoleh dari register pasien hemato-onkologi yang dirawat di Subdivisii Hemato-Onkologi Bagian/SMF Ilmu Kesehatan Anak FK UNUD/RS Sanglah Denpasar selama periode Januari 2000 sampai dengan Desember 2005. Data yang didapatkan selanjutnya disajikan dalam bentuk narasi dan tabel.

\section{Hasil}

Selama periode penelitian didapatkan 215 kasus yang terdiri dari 39 jenis penyakit yang masing-masing dapat dilihat pada Tabel 1. Leukemia limfoblastik akut (LLA) merupakan kasus yang terbanyak yaitu 23,7\%. Kasus

Tabel 1. Pola penyakit hemato-onkologi di Bagian/SMF Ilmu Kesehatan Anak FK UNUD/RS Sanglah periode 2000-2005

\begin{tabular}{lcc} 
Pola penyakit & Jumlah & Persentase (\%) \\
\hline Leukemia limfoblastik akut (LLA) & 51 & 23,7 \\
Purpura trombositopenik idiopatik (PTI) & 25 & 11,7 \\
Retinoblastoma & 17 & 7,9 \\
Anemia defisiensi besi & 13 & 6,0 \\
Limfoma maligna (non Hodgkin) & 11 & 5,1 \\
Thalasemia & 10 & 4,7 \\
Anemia aplastik & 10 & 4,7 \\
Anemia hipoplastik & 9 & 4,2 \\
Hemofilia A & 9 & 4,2 \\
Defisiensi vitamin K & 8 & 3,7 \\
Leukemia mieloblastk akut (LMA) & 6 & 2,8 \\
Von Willenbrand/ Pseudohemofilia & 6 & 2,8 \\
Anemia hemolitik autoimun (AHAI) & 5 & 2,3 \\
Meduloblastoma & 3 & 1,4 \\
Rabdomiosarkoma & 3 & 1,4 \\
Sindrom preleukemia & 3 & 1,4 \\
Neuroblastoma & 2 & 0,9 \\
Karsinoma testis & 2 & 0,9 \\
Anemia megaloblastik & 2 & 0,9 \\
Lain-lain: & 20 & 9,3 \\
Hemofilia B, tumor Willms, anemia karena penyakit kronik, sindrom Evans, kista dermoid, & & \\
anemia karena perdarahan akut, hiperplasia reaktif kelenjar limfe, osteosarkoma, limfoma & & \\
limfoblastik, anemia hemolitik karena gangguan eritropoesis, teratoma, anemia dismorfik, & & \\
mieloma multipel, sindrom Kasabach Merit, agnogenie myeloid metaplasia, anemia hemolitik & & \\
karena defisiensi G6PD, dismielopoisis, limfoma Hodgkin, histiositoma, sindrom & & \\
mielodisplastik. & & \\
Jumlah & 215 & 100,0 \\
\hline
\end{tabular}


lainnya berkisar antara $0,9 \%-11,7 \%$. Terdapat 20 kasus baru dengan jumlah masing-masing 1 kasus yaitu hemofilia B, tumor Willms, anemia karena penyakit kronik, sindrom Evans, kista dermoid, anemia karena perdarahan akut, hiperplasia reaktif kelenjar limfe, osteosarkoma, limfoma limfoblastik, anemia hemolitik karena gangguan eritropoesis, teratoma, anemia dismorfik, mieloma multipel, sindrom Kasabach Merit, agnogenie myeloid metaplasia, anemia hemolitik karena defisiensi G6PD, dismielopoisis, limfoma Hodgkin, histiositoma, dan sindrom mielodisplastik.

Dari 171 kasus hematologi, LLA merupakan kasus yang terbanyak (29,8\%); sedangkan dari 44 kasus onkologi, kasus yang terbanyak adalah retinoblastoma $(38,6 \%)$ (Tabel 2).

Berdasarkan jenis kelamin, sebagian besar kasus (130 kasus) adalah laki-laki dengan rasio laki-laki berbanding perempuan sebesar 1,53:1. Jika dilihat dari kelompok umur (Tabel 3), kebanyakan kasus (48,4\%) terdiagnosis pada umur $1-<5$ tahun. Hanya $7,4 \%$ terdiagnosis pada umur $=10$ tahun.

Dijumpai 85,6\% banyak pasien yang masih dapat bertahan dalam menjalani pengobatan setelah penegakkan diagnosis dilakukan, persentase pasien yang meninggal dan pulang paksa berturut-turut $8,4 \%$ dan 6,0\%, harus tetap diperhatikan (Tabel 4).

\section{Diskusi}

Kasus hemato-onkologi yang ada di Subdivisi HematoOnkologi Bagian/SMF Ilmu Kesehatan Anak FK UNUD/RS Sanglah Denpasar cukup beragam, meskipun proporsi terbanyak didominasi LLA. Kasus

Tabel 2. Pola penyakit hematologi dan onkologi di Bagian/SMF Ilmu Kesehatan Anak FK UNUD/RS Sanglah periode 2000-2005

\begin{tabular}{lcc}
\hline Pola penyakit & Jumlah & Persentase (\%) \\
\hline HEMATOLOGI & 171 & 100,0 \\
Leukemia limfoblastik akut (LLA) & 51 & 29,8 \\
Purpura trombositopenik idiopatik (PTI) & 25 & 14,6 \\
Anemia defisiensi besi & 13 & 7,6 \\
Thalasemia & 10 & 5,8 \\
Anemia aplastik & 10 & 5,8 \\
Anemia hipoplastik & 9 & 5,3 \\
Hemofilia A & 9 & 5,3 \\
Defisiensi vitamin K & 8 & 4,7 \\
Leukemia mieloblastik Akut (LMA) & 6 & 3,5 \\
Von Willenbrand/ Pseudohemofilia & 6 & 3,5 \\
Anemia hemolitik autoimun (AHAI) & 5 & 2,9 \\
Sindrom preleukemia & 3 & 1,8 \\
Anemia megaloblastik & 2 & 1,2 \\
Lain-lain: & 14 & 8,2
\end{tabular}

Hemofilia B, anemia penyakit kronik, sindrom Evans, anemia karena perdarahan akut, hiperplasia reaktif kelenjar limfe, anemia hemolitik karena gangguan eritropoesis, anemia dismorfik, mieloma multipel, sindrom Kasabach Merit, agnogenie myeloid metaplasia, anemia hemolitik karena defisiensi G6PD, dismielopoisis, histiositoma, sindrom mielodisplastik.

$\begin{array}{lcc}\text { ONKOLOGI } & 44 & 100,0 \\ \text { Retinoblastoma } & 1 & 38,6 \\ \text { Limfoma maligna (non Hodgkin) } & 11 & 25,0 \\ \text { Meduloblastoma } & 3 & 6,8 \\ \text { Rabdomiosarkoma } & 3 & 6,8 \\ \text { Neuroblastoma } & 2 & 4,6 \\ \text { Karsinoma testis } & 2 & 4,6 \\ \text { Lain-lain: } & 6 & 13,6 \\ \text { Tumor Willms, kista dermoid , osteosarkoma, limfoma limfoblastik, teratoma, limfoma Hodgkin. }\end{array}$


Tabel 3. Sebaran kasus berdasarkan kelompok umur

\begin{tabular}{ccc}
\hline Kelompok umur (tahun) & Jumlah kasus & Persentase (\%) \\
\hline$<1$ & 43 & 20,0 \\
$1-<5$ & 104 & 48,4 \\
$5-<10$ & 52 & 24,2 \\
$=10$ & 16 & 7,4 \\
\hline Jumlah & 215 & 100,0 \\
\hline
\end{tabular}

Tabel 4. Sebaran kasus berdasarkan keadaan saat pulang

\begin{tabular}{lcc} 
Keadaan saat pulang & Jumlah kasus & Persentase (\%) \\
\hline Hidup & 184 & 85,6 \\
Meninggal & 18 & 8,4 \\
Pulang paksa & 13 & 6,0 \\
\hline Jumlah & 215 & 100,0 \\
\hline
\end{tabular}

LLA merupakan kasus keganasan yang terbanyak terjadi pada anak, ${ }^{3,4}$ dan leukemia akut pada masa anak merupakan 30\%-40\% dari keganasan. Rerata insidens 4-4,5 kasus/tahun/100.000 anak di bawah 15 tahun. Di negara berkembang angka kejadian LLA $83 \%$ dan LMA (leukemia mieloblastik akut) $17 \%{ }^{1}$

Pada penelitian ini, perbandingan antara jenis kelamin laki-laki dan perempuan adalah sebesar 1,53 : 1. Hal ini menunjukkan bahwa anak laki-laki 1,5 kali lebih banyak dibandingkan dengan perempuan untuk mengalami kelainan hemato-onkologi. Hal ini bisa disebabkan karena kelainan hemato-onkologi banyak dihubungkan dengan genetik yang terkait dengan kromosom $\mathrm{x}$ seperti halnya pada penyakit hemofilia. ${ }^{2,5}$ Literatur menyatakan LLA banyak terjadi pada anak laki-laki dengan insidens tertinggi pada umur 3-4 tahun. Hal ini pula yang mungkin mendukung mengapa pasien terbanyak ditemukan pada kelompok umur $1-<5$ tahun. Terdapat frekuensi yang rendah setelah umur 10 tahun dengan kenaikan setelah umur 40 tahun. Insidens LMA didapatkan dalam jumlah sedikit karena LMA merupakan bentuk umum pada orang dewasa. ${ }^{6}$

Proporsi kasus meninggal pada penelitian ini terutama kasus LLA. Hal ini bisa dimengerti karena LLA mempunyai prognosis yang buruk. ${ }^{1,3,4}$ Mengenai pasien yang pulang paksa, hal ini disebabkan oleh karena proses diagnosis yang cukup rumit dan tata laksana yang membutuhkan waktu yang lama, membutuhkan kesabaran yang besar sehingga diperlukan jalinan kerjasama yang baik antara pasien, keluarga pasien, dokter dan paramedis, serta tenaga kesehatan lain yang terkait.

Kelemahan penelitian ini terletak pada desain penelitian yang bersifat retrospektif sehingga data yang didapat kurang lengkap, tetapi dapat dipakai sebagai data dasar untuk penelitian selanjutnya.

\section{Daftar Pustaka}

1. Permono B, Ugrasena IDG. Leukemia akut. Dalam: Permono B, Sutaryo, Ugrasena IDG, Windiastuti E, Abdulsalam M, penyunting. Buku ajar hematologionkologi anak. Edisi ke-1. Jakarta: Badan Penerbit IDAI; 2005.h.236-47.

2. Widjajanto PH. Biologi molekuler hemofilia. Kumpulan makalah workshop dan seminar hemofilia: penanganan terkini. Yogyakarta: Badan Penerbit FK UGM; 2003.h.510.

3. McKenna R. Acute lymphoblastic leukemia. Dalam: Kjeldsberg CR, penyunting. Practical diagnosis of hematologic disorders. Edisi ke-2. Chicago: Am Soc of Clin Pathol; 1995.h.411-37.

4. Niemeyer CM, Sallan SE. Acute lymphoblastic leukemia. Dalam: Nathan DG, Oskin SH, penyunting. Hematology of infancy and childhood. Edisi ke-5. Philadelphia: WB Saunders Company; 1998.h.124569.

5. Muslichan H. Hemofilia update. Dalam: Sudarmanto B, Setiati TE, Setyati J, penyuntring. Proceeding national meeting on hemophilia. Semarang: Balai Penerbit Universitas Diponegoro; 2004.h.1-10.

6. Hoffbrand AV, Petit JE. Essential haematology. Jakarta: EGC; 1996.h.127-59. 